\title{
CLOPIDOGREL RESPONSE IN ACUTE CORONARY SYNDROME PATIENTS WITH CYP2Y12*2 AND CYP2Y12*3 POLYMORPHISMS
}

\author{
Rahmatini R. ${ }^{1}{ }^{\star}$, Aliska G. ${ }^{1}$, Syafri M. ${ }^{2}$, Achyar A. ${ }^{3}$
}

Aim. This study aimed to look at the characteristics of the P2Y12 reactivity unit (PRU) in 30 Minang acute coronary syndrome (ACS) patients in Dr. M. Djamil Hospital, Padang, Indonesia.

Material and methods. This research was a cross-sectional study conducted in September 2016. The effectiveness of clopidogrel on platelet reactivity was identified through examination of PRU values using VerifyNow ${ }^{\circledR}$ with a cut-off point of 208. From the PRU values, it can be classified whether patients were resistant or responsive.

Results. This study shows that 30 patients with ACS who received clopidogrel, 24 patients $(80 \%)$ were male and 6 female patients (20\%). Hypertension was the greatest risk factor for the coronary arterial disease. A total of 11 patients $(36,77 \%)$ were resistant and 19 patients $(63,33 \%)$ were responsive to clopidogrel. About $46,67 \%$ patients were extensive metabolizers. PRU of these patients were lower than intermediate and poor metabolizers.

Conclusion. ACS patients with functional loss of CYP2C19 activity have lower platelet activity when treated with clopidogrel. Routine CYP2C19 and PRU testing may be warranted. Further research is needed with a larger number of patients to investigate the pharmacogenetic profile of CYP2C19 and the cause of clopidogrel resistance in Minang patients.

Russ J Cardiol 2018, 3 (155): 49-53

http://dx.doi.org/10.15829/1560-4071-2018-3-49-53
Key words: acute coronary syndrome, clopidogrel, CYP2C19 polymorphism, PRU.

Department of Pharmacology and Therapeutic, Faculty of Medicine, Andalas University, Padang; ${ }^{2}$ Department of Cardiology and Vascular Medicine Dr. M. Djamil Hospital and Faculty of Medicine, Andalas University, Padang; ${ }^{3}$ Biomedical Laboratory, Faculty of Medicine, Andalas University, Padang, Indonesia.

*Corresponding author: Rahmatini R., Department of Pharmacology and Therapeutic, Faculty of Medicine, Andalas University, Padang, Indonesia. fk.unand.rahmatini@gmail.com

ACS - acute coronary syndrome, CAD - coronary artery disease, CVCU cardiovascular care unit, LD - loading dose, LMICs - low and middle-income countries, $\mathrm{PCl}$ - percutaneous coronary intervention, $\mathrm{PRU}-\mathrm{P} 2 \mathrm{Y} 12$ reactivity unit.

Рукопись получена 26.12.2017

Рецензия получена 08.02.2018

Принята к публикации 21.02.2018

\section{ОТВЕТ НА КЛОПИДОГРЕЛ У ПАЦИЕНТОВ С ОСТРЫМ КОРОНАРНЫМ СИНДРОМОМ И ПОЛИМОРФИЗМАМИ СҮР2Ү12*2 И СҮР2Ү12*3}

Rahmatini R. ${ }^{\star}{ }^{\star}$, Aliska G. ${ }^{1}$, Syafri M. ${ }^{2}$, Achyar A. ${ }^{3}$

Цель. Оценить характеристики реактивности тромбоцитов по Р2Ү12 у 30 пациентов с острым коронарным синдромом (ОКС) на территории Минанг в стационаре доктора М. Джамил в Паданге, Индонезия.

Материал и методы. Исследование было кросс-секционным, в сентябре 2016 года. Эффективность клопидогрела во влиянии на реактивность тромбоцитов оценивалась при помощи VerifyNow ${ }^{\circledast}$ с порогом 208 единиц P2Y12-реактивности. По величине этого показателя можно оценить наличие ответа или резистентности у пациента.

Результаты. Среди 30 получавших клопидогрел пациентов 24 (80\%) были мужского пола. Самым важным фактором риска ОКС была гипертензия. Среди пациентов 11 (36,77\%) были резистентны и 19 (63,33\%) отвечали на клопидогрел. Около 46,67\% имели экстенсивную метаболическую активность. Реактивность по Р2Ү12 была ниже, чем при промежуточном и плохом метаболизме.

Заключение. Пациенты с ОКС и функциональной недостаточностью СҮР2C19 имеют сниженную активность тромбоцитов, когда получают клопидогрел.

Ischemic heart disease is the leading cause of death and disability in the world with a fairly high portion coming from low and middle-income countries (LMICs). Deaths due to ischemic heart disease and acute coronary syndrome (ACS) appear at a younger age in LMICs countries compared with high-income countries, often occurring during the productive years [1]. Data from the Jakarta Cardiovascular Study in 2008 at the Heart Hospital Harapan Kita shows the prevalence of myocardial
Рекомендуется рутинное тестирование СҮР2C19 и реактивности по Р2Ү12. Нужны дополнительные исследования с большим количеством пациентов для оценки фармакогенетического профиля СҮР2C19 и причин резистентности к клопидогрелу в Минанге.

Российский кардиологический журнал 2018, 3 (155): 49-53 http://dx.doi.org/10.15829/1560-4071-2018-3-49-53

Ключевые слова: острый коронарный синдром, клопидогрел, СҮР2С19 полиморфизм, Р2Y12.

'Отделение фармакологии и терапии, Медицинский факультет, Университет Андалас, Паданг; ${ }^{2}$ Отделение кардиологии и сосудистой медицины больницы д-ра М. Джамил и медицинского факультета, Университет Андалас, Паданг; ${ }^{3}$ Биомедицинская лаборатория, Медицинский факультет, Университет Андалас, Паданг, Индонезия.

infarction at 5,29\%-4,12\% and 7,6\% in women and men, respectively. Over the past seven years, the prevalence of myocardial infarction has increased by $4,09 \%$ or an average of $0,6 \%$ per year [2].

Clopidogrel is an irreversible inhibitor of the platelet P2Y12 adenosine diphosphate receptor, which is the standard drug therapy in the management of ACSs and in patients who will be undergoing percutaneous coronary intervention (PCI) [3-5]. Clopidogrel combined with 
aspirin is effective in preventing thrombosis of blood vessels repeatedly, for example, myocardial infarction and stroke. A member of the thienopyridine class of drugs, clopidogrel is administered in the form of a prodrug that must undergo biotransformation in the liver to become the active metabolite (R130964) in order to inhibit platelet aggregation. Approximately $85 \%$ of clopidogrel given orally and absorbed by the gastrointestinal tract undergoes hydrolysis by acarboxylesterase and inactivated by the enzyme. Only about $15 \%$ is metabolized in the liver via oxidation to produce the active form [3, 4].

CYP2C19 is the major enzyme in the biotransformation of clopidogrel. Genetic variations in this enzyme may affect clopidogrel activation and slow down the barriers of platelets during clopidogrel therapy [3]. Currently, there is no data about CYP2C19 polymorphism in Indonesian populations, especially ethnic Minang. This study aimed to obtain data regarding enzyme CYP2C19 polymorphisms in ethnic Minang. These were assessed by studying the P2Y12 platelet activity through assessing P2Y12 Reactivity Unit (PRU) in the blood of sampled individuals who had received clopidogrel. Knowledge of CYP2C19 polymorphisms in particular populations should be helpful guides for antiplatelet therapy in patients with the ACS.

\section{Material and methods}

Subjects. Our sample population was 30 patients with diagnosed ACS who received clopidogrel for the prevention of ischemic stroke in September 2016. This research is an observational study conducted prospectively in patients with ACSs who received clopidogrel therapy. This research was conducted in ward cardiology, cardiovascular care unit (CVCU), Biomedical Laboratory and Department of Pharmacology and Therapeutics, Faculty of Medicine, Andalas University, from August to November 2016.

The inclusion criteria of the subject are patients with a diagnosis of ACSs, male or female, age 18-65 years. Exclusion criteria are pregnancy, liver dysfunction, creatinine clearance $<30 \mathrm{ml} / \mathrm{min}$. Informed consent was obtained from each patient before study enrollment, and the study protocol was approved by the committee on ethics of Faculty of Medicine, Andalas University in Padang, Indonesia.

Data collection technique. Data were collected from medical records of all outpatient and inpatient Section Cardiovascular RSMD receiving clopidogrel therapy. The patient record data taken included characteristics/ demographic data (name, age, sex, weight, date of entry into care, medical record numbers), the results of anamnesis, physical examination, the results of initial laboratory examination, diagnosis and treatment of patients. The above data were used for the selection of research subjects.

Examination of genetic polymorphisms and PRU done using blood samples from patients. Blood samples were taken in patients who have been using clopidogrel loading dose (LD) and action PCI. Blood samples were taken at 48 hours after the loading dose. Blood samples were centrifuged to obtain blood plasma. Plasma is stored at a temperature of minus $20^{\circ} \mathrm{C}$ until the sample size is met. Genomic DNA extractions from whole blood for PCR were carried out simultaneously after all samples collected. Polymorphism data obtained from PCR were performed in Biomedical Laboratory Faculty of Medicine, Andalas University.

Data on PRU values were obtained from examinations conducted at the central laboratory of Dr. M. Djamil hospital, Padang. Examination of platelet reactivity was performed within four hours from blood sampling. Examination of clopidogrel inhibitory activity against $\mathrm{P} 2 \mathrm{Y} 12$ receptor (P2Y12 reactivity unit) was measured by using VerifyNow ${ }^{\circledR}$ software and was performed at the cardiovascular ward, Dr. M. Djamil hospital.

Examination of genetic polymorphisms. Genomic DNA was extracted from frozen anti-coagulated whole blood samples from each of the 30 subjects using a GF-1 Blood DNA Extraction Kit (Vivantis, catalog number GF-BD050) according to the manufacturer's instructions. Genomic DNA concentration and purity was quantified in duplicate using NanoDrop spectrophotometer. DNA samples were stored at $-20^{\circ} \mathrm{C}$.

Examination of CYP2C19 polymorphisms used the polymerase chain reaction (PCR) followed by DNA sequencing. CYP2C19 exon 5 was amplified for detection from the CYP2C19*2 allele (rs4244285 G>A) using primer 2C19Ex5U (5'-CAGAGCTTGGCATATTGTATC-3') and 2C19Ex5L (5'-GTAAACACACAACTAGTCAATG-3'), while CYP2C19 exon 4 was amplified for detection from the CYP2C19*3 allele (rs4986893 G>A) using primer 2C19Ex4U (5'-TAT GAA GTG TTT TAT ATC TAA TGT TTA CTC A-3') and 2C19Ex4L (5'-ACT TCA GGG CTT GGT CAA TAT AGA-3'). The primers were adopted from Hersberger, et al. [6].

CYP2C19*2 PCR reactions were performed in a $25 \mu \mathrm{l}$ total volume that contained $400 \mathrm{nM}$ primer $2 \mathrm{C} 19 \mathrm{Ex} 5 \mathrm{U}$ and $400 \mathrm{nM}$ primer 2C19Ex5L (synthesized by Integrated DNA Technologies, Singapore), 1x GoTaq Green Master mix (Promega, catalog number M7122), and $2 \mu 1$ DNA template. The cycling conditions were initial denaturation at $95^{\circ} \mathrm{C}$ for 3 minutes followed by 35 cycles of denaturation at $95^{\circ} \mathrm{C}$ for 30 seconds, annealing at $58^{\circ} \mathrm{C}$ for 30 seconds and extension at $72^{\circ} \mathrm{C}$ for 30 seconds, and followed by final extension at $72^{\circ} \mathrm{C}$ for 5 minutes, using T100 thermocycler (Bio-Rad, USA). The reaction of CYP2C19*3 PCR also performed in different PCR tube with the same reaction above except the primer, $300 \mathrm{nM}$ primer 2C19Ex4U and $300 \mathrm{nM}$ primer 2C19Ex4L, and the annealing temperature was $60^{\circ} \mathrm{C}$. A total of $5 \mu \mathrm{l}$ of each PCR product was separated and visualized by $1,5 \%$ agarose gel staining with GelRed (Biotium). CYP2C19*2 and CYP2C19*3 PCR product sizes were $321 \mathrm{bp}$ and 309 $\mathrm{bp}$, respectively. The remained PCR products were 


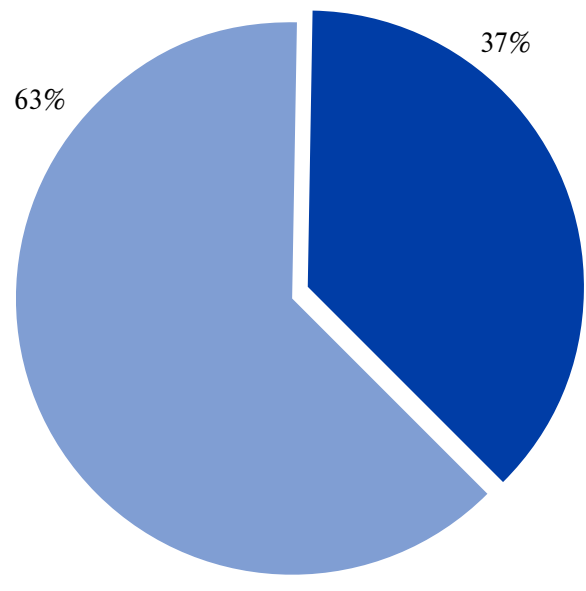

Resistant

Responsive

Fig. 1. Value PRU based on the cut-off point.

washed using $3 \mathrm{M}$ sodium acetate and chilled with absolute ethanol.

The purified PCR products were sent for sequencing using a Sanger DNA sequencing method to Macrogen, Inc., South Korea. Then the DNA sequences were analyzed using Geneious 7.0.6 bioinformatics software. The results were classified as the extensive, intermediate, and poor metabolizer. The extensive metabolizer was defined as a patient who had a homozygous wild-type genotype $\left(\mathrm{CYP} 2 \mathrm{C} 19^{*} 1{ }^{*} 1\right)$. The intermediate metabolizer was defined as a patient who had a heterozygous genotype with at least one CYP2C19*1 allele (CYP2C19*1/*2 or $* 1 /{ }^{*} 3$ ), and a poor metabolizer was classified as a patient who had a homozygous $(C Y P 2 C 19 * 2 / * 2$ or $* 3 / * 3)$ or heterozygous $\left(\mathrm{CYP} 2 \mathrm{C} 19^{*} 2 /{ }^{*} 3\right)$ genotype with a mutant allele [7].

Statistical analysis. Basic characteristic data were presented with descriptive statistics. The Shapiro-Wilk test was used to test for normal distribution. The relationship between CYP2C19 metabolizers with PRU values was assessed using the Kruskal-Wallis One-Way ANOVA on ranks. Results are considered significant when $\mathrm{p}<0,05$. Quantitative data collected was processed and analyzed using SPSS version 17.0.

\section{Results}

We enrolled 30 patients with ACS who were treated at the Dr. M. Djamil hospital who met the inclusion criteria and had signed an informed consent. The age range was $38-75$ years, with a mean age of 57,30 years. A total of $80 \%$ of the subjects were male, and $20 \%$ female. Almost all patients had risk factors for coronary artery disease (CAD) with only one patient without any risk factors. Smoking and hypertension were the biggest risk factors of CAD $(56,67 \%)$ for the subject of the study, followed by diabetes mellitus, dyslipidemia and menopause (Tab. 1).
Baseline characteristics of patients

\begin{tabular}{|c|c|}
\hline Variable & Patients ( $n=30$ ) \\
\hline Age, year, mean $\pm S D$ & $57,30 \pm$ \\
\hline \multicolumn{2}{|l|}{ Sex } \\
\hline Male & $24 / 30$ (80\%) \\
\hline Female & $6 / 30(20 \%)$ \\
\hline \multicolumn{2}{|l|}{ Risk factors } \\
\hline Yes & $29 / 30(96,67 \%)$ \\
\hline No & $1 / 30(3,33 \%)$ \\
\hline \multicolumn{2}{|l|}{ Smokers } \\
\hline Yes & $17 / 30(56,67 \%)$ \\
\hline No & $13 / 30(43,33 \%)$ \\
\hline \multicolumn{2}{|l|}{ Hypertension } \\
\hline Yes & $17 / 30(56,67 \%)$ \\
\hline No & $13 / 30(43,33 \%)$ \\
\hline \multicolumn{2}{|l|}{ Diabetes Mellitus } \\
\hline Yes & $4 / 30(13,33 \%)$ \\
\hline No & $26 / 30(86,67 \%)$ \\
\hline \multicolumn{2}{|l|}{ Dyslipidemia } \\
\hline Yes & $3 / 30(10 \%)$ \\
\hline No & $27 / 30(90 \%)$ \\
\hline \multicolumn{2}{|l|}{ Menopause } \\
\hline Yes & $4 / 30(13,33 \%)$ \\
\hline No & $26 / 30(86,67 \%)$ \\
\hline
\end{tabular}

Table 2

\section{Overview of CYP2C19 sequencing}

\begin{tabular}{|l|l|l|}
\hline Phenotype of gene CYP2C19 & CYP2C19*2(n/\%) & CYP2C19*3 (n/\%) \\
\hline Wild type & $16 / 53,33$ & $27 / 90$ \\
\hline Heterozygous Mutant & $11 / 36,67$ & $2 / 6,7$ \\
\hline Homozygous Mutant & $3 / 10$ & $1 / 3,3$
\end{tabular}

Results from the PRU testing indicated $63,3 \%$ of the study subjects with PRU values $<208$ were classified as responsive patients, and $36,7 \%$ of the study subjects with PRU values $>208$ patients were classified as resistant (Fig. 1). Results from the sequencing of alleles CYP2C19*2 and CYP2C19*3 showed that the proportion of wild-type patients is still high. Although some patients were homozygous mutant.

\section{Discussion}

Among of the research subjects only one was aged under 40 years. There are various risk factors that facilitate the occurrence of ischemic heart disease. Most patients with ACS have an acute manifestation of coronary artery plaque, atheromatous tear, or rupture. This situation is followed by a process of platelet aggregation and activation of the coagulation pathway, forming a platelet-rich thrombus. This thrombus can clog a coronary artery, either totally or partially. Some extrinsic factors such as fever, 
Table 3

Patient characteristics according to CYP2C19 metabolizer subgroup

\begin{tabular}{|l|l|l|l|}
\hline & Extensive & Intermediate & Poor \\
\hline Number of patients & $14(46,7)$ & $12(40,0)$ & $4(13,3)$ \\
\hline Male sex & 11 & 9 & 4 \\
\hline Age & $54,4 \pm 9$ & $59,0 \pm 7,9$ & $62,5 \pm 7,7$ \\
\hline Smoker & 6 & 9 & 2 \\
\hline Hypertension & 10 & 5 & 1 \\
\hline Diabetes Mellitus & 2 & 1 & 1 \\
\hline Dyslipidemia & 1 & 1 & 2 \\
\hline
\end{tabular}

Table 4

PRU value among CYP2C19 metabolizer subgroup

\begin{tabular}{|l|l|l|l|l|}
\hline & Extensive & Intermediate & Poor & p-value \\
\hline PRU & $157 \pm 66$ & $170 \pm 79$ & $184 \pm 91$ & 0,431 \\
\hline
\end{tabular}

anemia, thyrotoxicosis, hypotension, tachycardia can trigger the occurrence of ACS in patients who already have plaque atherosclerosis [8]. In accordance with the literature, patients with acute coronary syndromes were primarily male. This study also found almost all subjects had other risk factors such as diabetes, hypertension, dyslipidemia and menopause. Clopidogrel resistance is a condition in which clopidogrel is less effective in certain patients [9]. This study found $37 \%$ of subjects had clopidogrel resistance (Fig. 1). Patients with clopidogrel resistance are at risk of serious complications, which are sometimes fatal. These patients may experience a heart attack or stroke caused by abnormal blood clot formation. Stents can cause blood clots (thrombosis) that can block blood flow.

This study found that $63 \%$ of the subjects were still responsive to clopidogrel, based on PRU value. This result was in line with the results from sequencing the CYP2C19*2 and CYP2C19*3 exons, which showed that the number of wild-type alleles was much higher than that the mutant alleles (homozygous and heterozygous) in the subject population (Tab. 2). This showed the genetic variants that modulate the absorption and metabolism of clopidogrel could also impact on clopidogrel response [9, 10]. A point mutation in CYP2C19 gene could lead to a defective or nonfunctional protein, or inactive enzyme, resulting in the lack of ability to metabolize clopidogrel into an active metabolite [7].

About 46,7\% patients were extensive metabolizers (Tab. 3). Similar to the results seen by Gonzalez, et al. $45 \%$ of carotic artery stenting patients were extensive metabolizers [4]. Baseline PRU was significantly higher among intermediate-poor metabolizers compared with ultra-rapid or extensive metabolizers. In our patients, PRUs among intermediate-poor metabolizers were higher than extensive metabolizers but not significant (Tab. 4). Subraja et al. found a higher proportion of extensive metabolizers $(62,3 \%)$ among cerebrovascular patients [11]. Lee, et al. found that extensive metabolizers had significantly lower PRU than intermediate-poor metabolizers [12]. Poor metabolizers should not be treated with clopidogrel [13]. Determination of CYP2C19 polymorphism could increase the effectiveness of antithrombotic therapy.

Our study has some important limitations. It is a single-center study with a small number of patients. It is advisable in future studies to involve a greater number of subjects so that it is more representative of the population. The need remains for examination of plasma levels of clopidogrel to determine the effects of polymorphisms of genes encoding the metabolism and absorption is the reduction in plasma levels of clopidogrel so that correlations between genetic polymorphisms with drug levels in the blood can be assessed.

\section{Conclusion}

ACS patients with functional loss of CYP2C19 activity have lower platelet activity when treated with clopidogrel. Routine CYP2C19 and PRU testing may be warranted. Further research is needed with a larger number of patients to investigate the pharmacogenetic profile of CYP2C19 and the cause of clopidogrel resistance in Minang patients.

\section{Conflict of Interest}

Authors declare that there is no conflict of interest. 


\section{References}

1. Vedanthan R, Seligman B, Fuster V. Global perspective on acute coronary syndrome: a burden on the young and poor. Circ Res 2014; 114 (12): 1959-75.

2. Melati R, Basuki E, Setianto B. Relationship between job strain and myocardial infarction in the national cardiovascular patient center. J Kardiol Ind 2008; 29 (1): 12-9.

3. Ogawa H, Isshiki T, Kimura $\mathrm{T}$, et al. Effects of CYP2C19 allelic variants on inhibition of platelet aggregation and major adverse cardiovascular events in Japanese patients with acute coronary syndrome: The PRASFIT-ACS study. J Cardiol 2016; 68 (1): 29-36.

4. González A, Moniche F, Cayuela A, et al. Effect of CYP2C19 polymorphisms on the platelet response to clopidogrel and influence on the effect of high versus standard dose clopidogrel in carotid artery stenting. Eur J Vasc Endovasc Surg 2016; 51 (2): 175-86.

5. Rehman KU, Akhtar T, Sabar MF, et al. Allele frequency distribution of CYP2C19*2 allelic variants associated with clopidogrel resistance in cardiac patients. Exp Ther Med 2015; 10 (1): 309-15.

6. Hersberger M, Marti-Jaun J, Rentsch K, et al. Two single-tube tetra-primer assays to detect the CYP2C19*2 and *3 alleles of S-mephenytoin hydroxylase. Clin Chem 2001; 47 (4): $772-4$.

7. Sukasem $C$, Tunthong $R$, Chamnanphon M, et al. CYP2C19 polymorphisms in the Thai population and the clinical response to clopidogrel in patients with atherothrombotic-risk factors. Pharmgenomics Pers Med 2013; 6: 85-91.
8. Indonesian Heart Association. Pedoman tatalaksana sindrome koroner akut. Centra Communications; 2015. p.11-35.

9. Hamm CW, Bassand JP, Agewall S, et al. ESC guidelines for the management of acute coronary syndromes in patients presenting without persistent ST-segment elevation: The Task Force for the management of acute coronary syndromes (ACS) in patients presenting without persistent ST-segment elevation of the European Society of Cardiology (ESC). Eur Heart Journal 2011; 32 (23): 2999-3054.

10. Zehnder JL. Drugs used in disorders of coagulation. In: Katzung BG, Masters SB, Trevor AJ, eds. Basic \& Clinical Pharmacology. 11th ed. Singapore: McGraw-Hill, 2009: p.598-99.

11. Subraja K, Dkhar SA, Priyadharsini R, et al. Genetic polymorphisms of CYP2C19 influences the response to clopidogrel in ischemic heart disease patients in the South Indian Tamilian population. Eur J Clin Pharmacol 2013; 69 (3): 415-22.

12. Lee JB, Lee $\mathrm{KA}$, Lee $\mathrm{KY}$. Cytochrome $\mathrm{P} 4502 \mathrm{C} 19$ polymorphism is associated with reduced clopidogrel response in cerebrovascular disease. Yonsei Med Journal 2011; 52 (5): 734-8.

13. Scott SA, Sangkuhl K, Stein CM, et al. Clinical pharmacogenetics implementation consortium. clinical pharmacogenetics consortium implementation guidelines for CYP2C19 genotype and clopidogrel therapy: 2013 update. Clin Pharmacol Ther 2013 94 (3): 317-23. 